\title{
Long-term grazing study in spring-fed wetlands reveals management tradeoffs
}

\author{
Barbara Allen-Diaz \\ Randall D. Jackson \\ James W. Bartolome \\ Kenneth W. Tate \\ Lawrence G. Oates
}

$\nabla$

Spring-fed wetlands perform many important functions within oakwoodland landscapes, and livestock grazing modifies these functions. We used 10-year (long-term) and 3-year (paired-plot) experiments to better understand grazing management effects. We studied spring ecosystem responses in plant composition, diversity and cover; channel morphology; water quality; aquatic insects; and greenhouse gases. Lightly and moderately grazed wetlands exhibited lower insect family richness than ungrazed springs. Plant cover was maintained for the first 7 years of grazing, and plant diversity was not significantly affected. At the same time, removal of grazing decreased emissions of the greenhouse gas methane, and increased nitrate levels in spring waters. The results reveal important management tradeoffs relative to key response variables. In general, light cattle grazing at springs appears to be desirable from an ecosystem function perspective.

W etland ecosystems are highly productive and valued for numerous reasons including wildlife habitat, biodiversity, water quantity and quality, and human uses. They are also relatively small ecosystems, occupying less than $1 \%$ of the state. Because livestock are thought to damage the physical, chemical and biological integrity of these systems, they are subject to government regulations, ranging from seasonal use

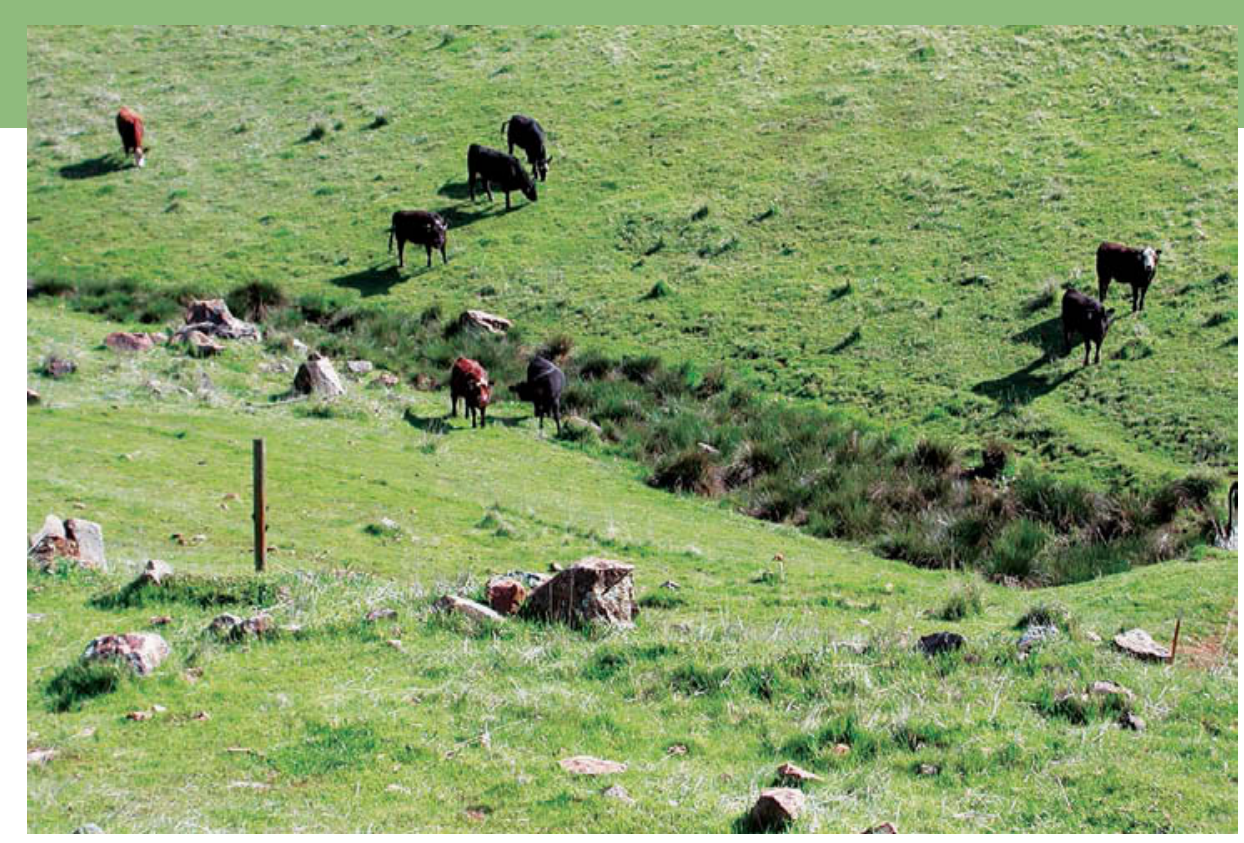

Oak-woodland springs provide green habitat and water throughout California's Mediterranean-style dry season, making them highly desirable ecosystems, islands of biodiversity and high productivity.

requirements to complete livestock removal (Allen-Diaz and Jackson 2002). Livestock grazing can affect the functioning of spring-fed wetlands by acting as a nutrient filter and altering plant community composition (Jackson 2002).

These systems are also highly variable, making it difficult to predict responses to management (Allen-Diaz et al. 2001). For example, first-order (headwater) and fourth-order streams (such as the Yuba River) may have similar vegetation, but their responses to grazing may differ because of substrate (the bedrock, gravels and soils on which plants grow), slope or other environmental differences.

Spring-fed wetlands of the oak woodlands fall into two broad categories - rocky and marshy (Allen-Diaz and Jackson 2000). Where spring water emerges in and around rocky substrates, little soil development occurs. Water quickly forms channels, and overstory trees and shrubs are frequently present. The rocky wetlands typically maintain two distinct zones, an area immediately surrounding the emergent water source (referred to as springs) and the resulting channelized creek (fig. 1A).
On more shallow slopes, the flow of emergent water is slower and more diffuse, allowing the development of dense, herbaceous vegetation, which further reduces flow. These marshy sites typically do not support trees or shrubs, probably because of anaerobic soil.

\section{Grazing and soil-water research}

Rangelands occupy about 57 million acres in California. About $42 \%$ of these acres are privately owned and provide most of the forage for California's cattle industry. Approximately 9,000 miles of streams and 125,000 acres of wetlands occur on California rangelands. Many consider livestock grazing on rangeland a potential nonpoint source of pollution and thus, a serious threat to the health of California waters. Our research carefully examines these concerns.

In a long-term study, Experiment $\mathrm{A}$, we tracked species composition and cover for more than a decade, primarily on rocky-type wetlands, under three levels of grazing intensity at the UC Sierra Foothill Research and Extension Center (SFREC) east of Marysville, Calif. (Allen-Diaz and Jackson 2000). Species composition was recorded in early June 

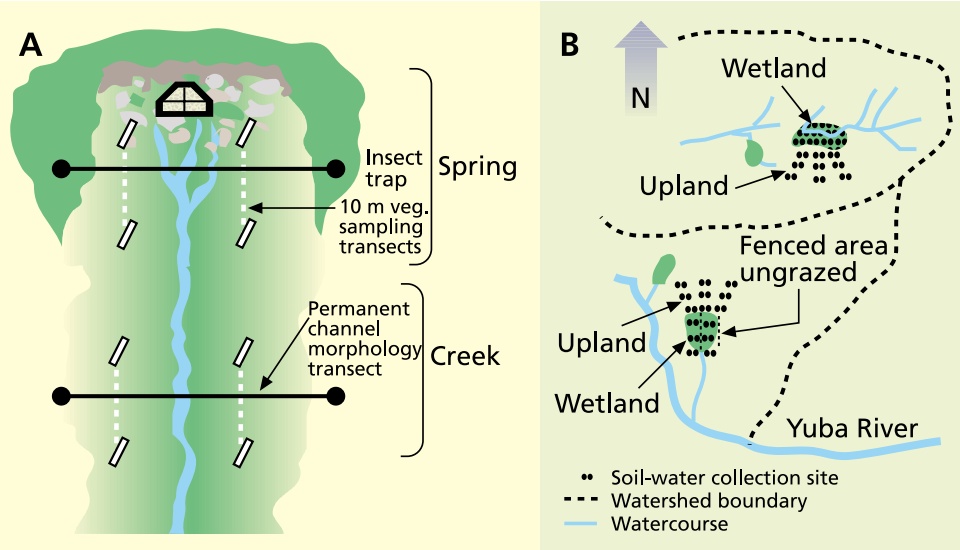

Fig. 1. Typical morphology of rocky spring-fed wetlands; Experiment (A) and (B) study layouts.

each year from permanent 16.25- or 32.5-foot (5- or 10-meter) line-point transects, which were randomly located on either side of the channel within the wetland zone. Changes in streamchannel shape (morphology)(Allen-Diaz et al. 1998) and water quality (Campbell and Allen-Diaz 1997) were also examined for approximately 5 -year periods on the same sites (fig. 2). Channel morphology changes were recorded along two randomly placed 32.5-foot (10-meter) line-point transects located perpendicular to the flow of the spring or creek. We collected water samples at the springhead, or spring source, and in the creek and analyzed them in the field using a HACH DREL2000 Water Testing Kit.

In a paired-plot study at the SFREC, Experiment $B$, we examined marshy springs to closely evaluate soil-water nitrate levels and greenhouse-gas emissions for 3 years. We collected soil water from preinstalled, porous, soil-water cup samplers (Model 1900, SoilMoisture Equipment, Santa Barbara). When possible, samples of upland soil water and wetland surface water were collected monthly (fig. 1B). Within the wetland, surface-water samples were collected in 100-milliliter $(\mathrm{mL})$ specimen cups to assess nitrate output and compare with upland soil-nitrate levels. The UC Division of Agriculture and Natural Resources Analytical Laboratory analyzed water samples by a diffusion-conductivity analyzer. Carbon $\left(\mathrm{CO}_{2}\right)$, nitrogen $\left(\mathrm{N}_{2} \mathrm{O}\right)$ and methane $\left(\mathrm{CH}_{4}\right)$ gas emissions were collected monthly from March to Sep-

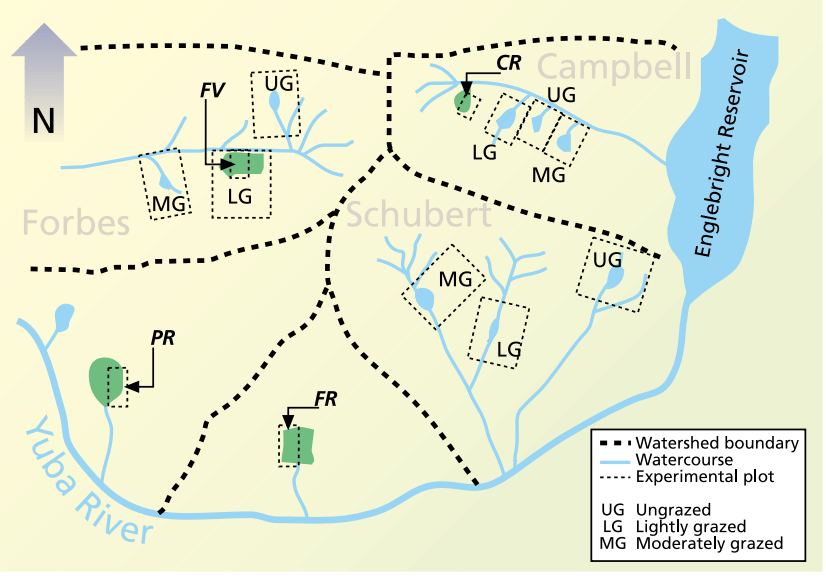

Fig. 2. Location of experimental plots at the UC Sierra Foothill Research and Extension Center. The 10-year (Experiment A) sites were in Forbes, Campbell and Schubert watersheds; the 3-year study (Experiment B) sites were Forbes Valley (FV), Poleline Ridge (PR), Campbell Roadside (CR) and Fireline Ridge (FR). tember 2002 (with the exception of May) in vented static flow chambers. Gas samples were analyzed by gas chromatography (SRI Instruments, Torrance, Calif.).

All sites had historically similar fallwinter-spring grazing histories that left approximately 600 to 750 pounds per acre residual dry matter (RDM), or aboveground biomass, in the uplands. In 1993, sites within watersheds were randomly assigned to the following treatments in a randomized block design:

- Grazing removal (ungrazed, UG, approximately 1,200 to 1,500 pounds per acre upland RDM).

- Light grazing (LG, approximately 800 to 1,000 pounds per acre upland RDM).

- Moderate grazing (MG, approximately 600 to 700 pounds per acre upland RDM).

Experiment B took place on the marshy sites, to take advantage of their greater area. Marshy springs were sampled in 1999 and 2000. Then, these sites were divided so that grazing treatment comparisons could be made within sites (Jackson 2002). This meant that only two treatment levels could be compared moderate grazing and grazing removal. Posttreatment samples were collected in 2001 (fig. 2).

\section{Grazing effects on wetlands}

Plant species composition. Changes in species composition provided evidence of fundamentally different vegetation dynamics in these systems. One way to examine these changes is with a CCA (Canonical Correspondence Analysis) site score, an index variable that collapses species composition into one measure. This statistical technique is useful for interpreting plant community structure that is related to environmental variables (McCune and Grace 2002). For example, in this case we used it to compare changes in species composition related to grazing levels in Experiment A. The CCA site scores were much more variable from year to year for springs than for creeks on the rocky-type wetlands (fig. 3). Implications for management are that species composition can be manipulated by altering the grazing intensity along creeks. In springs, how-

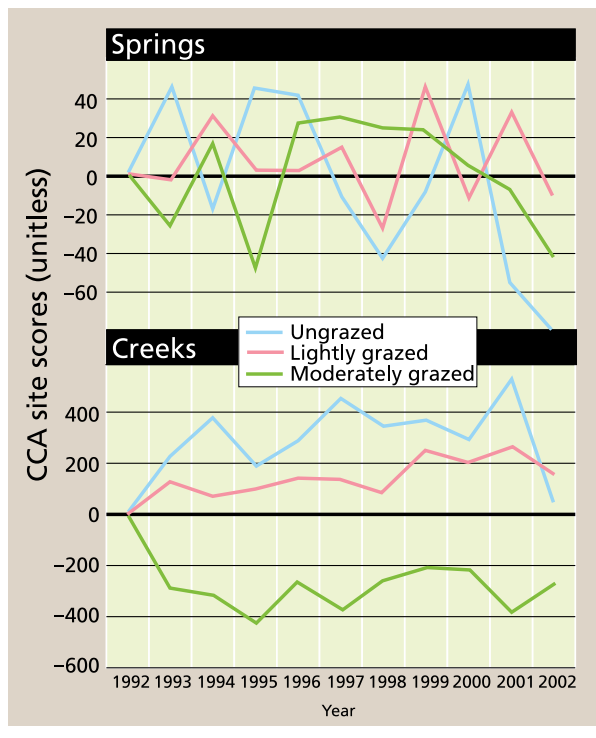

Fig. 3. Species composition over time as affected by grazing intensity in Experiment $A$. 


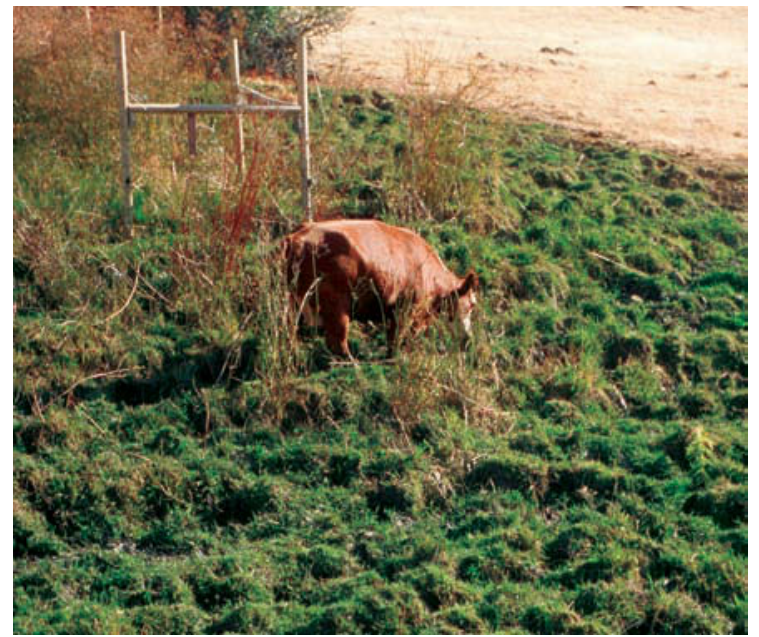

Cattle grazing causes visual changes in oak-woodland spring structure. However, spring composition is stable over time, and hoof-caused hummocks do not result in detrimental changes to composition, productivity or water quality.

ever, species composition is controlled by the vagaries of climate, not by grazing intensities at the levels we studied.

Herbaceous diversity. No significant differences in the total number of species (relative to pretreatment 1992 values) were observed at any of the wetland sites. Common species are listed in table 1 . In both experiments, there were no changes in the relative amounts of native and nonnative species over time under any grazing treatment. Lightly grazed wetlands maintained greater species evenness (maximum when all species have the same number of individuals) and diversity (Shannon-Weaver and Simpson indices) relative to 1992 pretreatment values than either ungrazed or moderately grazed plots (Jackson 2002). At creeks, moderately grazed plots maintained greater relative total species, evenness and diversity than lightly grazed and ungrazed plots, which were not significantly different from each other.

On marshy springs (Experiment B), we observed decreased diversity with grazing removal for 1 year. Our results indicate that light grazing on spring-fed wetlands and moderate grazing on resultant down-slope creeks maintain current plant diversity.

Herbaceous cover. Because plant cover conserves soil, improves water quality and is correlated with plant productivity, it is an important measure of ecosystem health. After 7 years, we found no significant differences in herbaceous cover among grazing intensity treatments. However, by 2002, moderate grazing resulted in a significant decrease in plant cover. Sustained grazing at moderate or higher intensities on these systems is not desirable from an ecosystem conservation perspective, to prevent significant erosion and prevent undesirable changes in species composition. However, our short-term study showed that occasional moderate grazing does not significantly affect plant cover.

Channel morphology. Five years of data from permanent cross-section transects of the springs and resultant creeks in Experiment A showed no changes in channel morphology due to grazing treatment (Allen-Diaz et al. 1998). Ungrazed springs and creeks exhibited more year-to-year variability than grazed springs and creeks, although these differences were not statistically significant. Channel widening and flattening of waterways can have important effects on fish populations, especially in second and lower-order streams.

Water quality. Over a 5-year period we monitored nitrate, orthophosphate, dissolved oxygen, temperature and $\mathrm{pH}$ in surface water emerging from rocky spring-fed systems. We found no

TABLE 1. Dominant herbaceous-layer plant species in springs and creeks at Sierra Foothill Research and Extension Center, Experiments A and B

\begin{tabular}{lllc}
\hline \hline Common name & Species & Family & $\begin{array}{c}\text { Native/ } \\
\text { introduced* }\end{array}$ \\
\hline Blue wild-rye (H) & Elymus glaucus & $\mathrm{N}$ \\
California blackberry (C) & Rubus ursinus & Poaceae & $\mathrm{N}$ \\
California grape & Vitis californica & Rosaceae & $\mathrm{N}$ \\
Common spike-rush & Eleocharis macrostachya & Vitaceae & $\mathrm{N}$ \\
Dallis grass (F) & Paspalum dilatatum & Poaceae & $\mathrm{I}$ \\
Dogtail (B) & Cynosurus echinatus & Poaceae & $\mathrm{I}$ \\
False brome & Brachypodium distachyon & Poaceae & $\mathrm{I}$ \\
Flat sedge & Cyperus odoratus & Cyperaceae & $\mathrm{N}$ \\
Hedge nettle & Stachys albens & Lamiaceae & $\mathrm{N}$ \\
Italian ryegrass (E) & Lolium multiflorum & Poaceae & $\mathrm{I}$ \\
Italian thistle & Carduus pycnocephalus & Asteraceae & $\mathrm{I}$ \\
Narrow-leaved cattail (G) & Typha angustifolia & Typhaceae & $\mathrm{N}$ \\
Rabbitfoot grass (D) & Polypogon monspeliensis & Poaceae & $\mathrm{I}$ \\
Rattlesnake grass & Briza minor & Poaceae & $\mathrm{I}$ \\
Ripgut brome & Bromus diandrus & Poaceae & $\mathrm{I}$ \\
Seashore vervain & Verbena litoralis & Verbenaceae & $\mathrm{I}$ \\
Soft chess & Bromus hordeaceus & Poaceae & $\mathrm{I}$ \\
Velvet grass (A) & Holcus lanatus & Poaceae & $\mathrm{I}$ \\
Water cress & Rorippa nasturtium-aquaticum & Brassicaceae & $\mathrm{N}$ \\
\hline
\end{tabular}

* $\mathrm{N}=$ native, $\mathrm{I}=$ introduced (Hickman 1993).

Photo credits: Joseph M. DiTomaso (A-E), Jack Kelly Clark (F), ANR Communication Services (G), Suzanne Paisley (H).

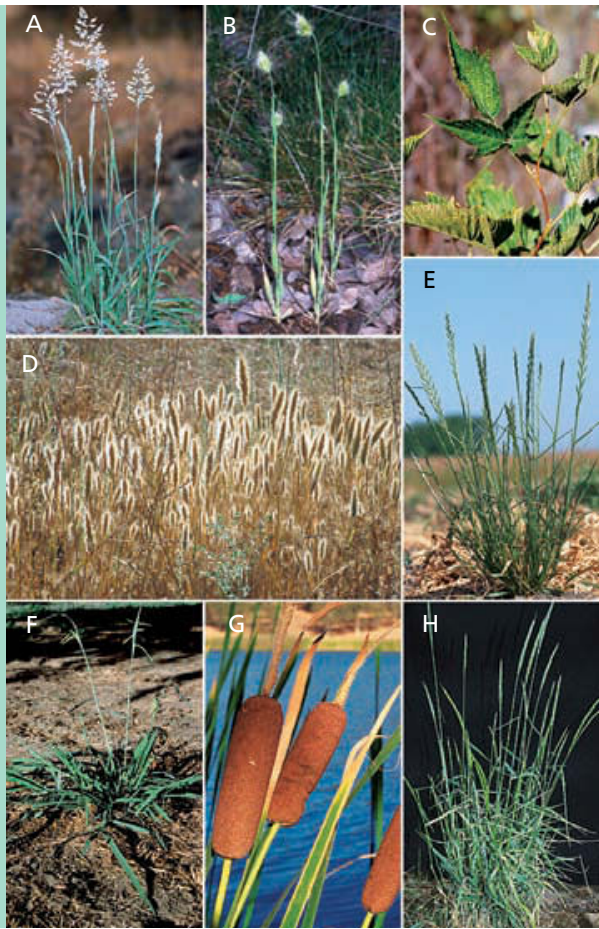




\section{Removal of livestock grazing resulted in increased levels of nitrate in wetland waters and thus higher levels of nitrate pollution compared to grazed springs.}

significant differences among grazing intensity treatments in Experiment A (Campbell and Allen-Diaz 1997).

In Experiment B, marshy springfed wetlands appeared to intercept and retain nitrate as it moved along its hydrologic path from upland soils to emergent spring waters (Jackson and Allen-Diaz 2002). Furthermore, the removal of livestock grazing from these wetlands impaired the ability of the springs to retain nitrate. Grazing removal allowed dead plant material to accumulate (fig. 4), thereby inhibiting plant production (hence, plant nitrogen demand), resulting in stream-water nitrate concentrations that far exceeded the U.S. Environmental Protection Agency's surface-water maximum standard of $714 \mu \mathrm{mol}^{5}$ (micromoles ${ }^{5}$ or 10 parts per million [ppm])(fig. 5).

Aquatic insects. Aquatic insects are frequently used to evaluate the ecological integrity of streams. Reduced community numbers may indicate organic pollution or habitat degradation. Insects were identified to the family level from a 1-year sample (collected quarterly) in Experiment A. Analysis was limited to families with aquatic genera; wholly terrestrial families were excluded. Lightly grazed and moderately grazed wetlands exhibited lower family richness than ungrazed springs at each sampling date. The lowest cumulative family-richness values (sum of all families for the year) were found for moderately grazed springs followed by lightly grazed springs.

Greenhouse gases. Methane $\left(\mathrm{CH}_{4}\right)$ is a greenhouse gas that is important to global climate change. It is "radiatively active," warming the lower atmosphere by absorbing thermal radiation. Methane contributes approximately $20 \%$ of terrestrial trace gases into the atmosphere (Bouwman 1990; Cicerone and Oremland 1988). The atmospheric concentration of methane has increased from 0.7 to $1.7 \mathrm{ppmv}$ (parts per million by volume) in the last 200 years (Tyler 1991). When compared to carbon dioxide $\left(\mathrm{CO}_{2}\right)$, the relative contribution of methane to the Earth's energy balance exceeds its relative concentration in the biosphere. This is because methane generally absorbs reflected radiation 25 times more effectively than carbon dioxide (Bartlett and Harriss 1993).

Wetland systems are generally considered sources of methane because biomass rots in anaerobic conditions (Schlesinger 1997). We assessed the effects of grazing on methane fluxes (the amount released into the air) in springfed wetlands in Experiment B (Oates 2002). Air temperature had the strongest influence on methane flux, followed by soil water content and grazing presence or absence. The mean methane flux was $9.29 \pm 4.37 \mathrm{mg} \mathrm{CH}-\mathrm{C} / \mathrm{m}^{-2} / \mathrm{hr}^{-1}$ (mean \pm S.E.) with a range of -0.19 to 147.88 $\mathrm{mg} \mathrm{CH}-\mathrm{C} / \mathrm{m}^{-2} / \mathrm{hr}^{-1}$ (methane flux measured as carbon in the form methane in milligrams per square meter per hour). Water content at these sites was $39.66 \% \pm$ $2.29 \%$, with a range of $14.51 \%$ to $60.64 \%$. Grazing removal significantly decreased methane emissions; grazed was $16.01 \pm$ $8.48 \mathrm{mg} \mathrm{CH}_{4}-\mathrm{C} / \mathrm{m}^{-2} / \mathrm{hr}^{-1}$, and ungrazed was $2.57 \pm 1.15 \mathrm{mg} \mathrm{CH}_{4}-\mathrm{C} / \mathrm{m}^{-2} / \mathrm{hr}^{-1}$.

\section{Guidelines and research gaps}

Spring-fed wetlands are small, patchy ecosystems nestled within a matrix of oaks and annual species; they are important in overall landscape structure and function in a way that is disproportionate to their size. Much of the water exiting California oak-woodland watersheds passes through these highly productive spring-riparian zones, which are located at the interface of the terrestrial-aquatic ecosystem. Our data indicates that wetland vegetation in these zones, typically cattails (Typha angustifolia), sedges, rushes and perennial grasses, act as nutrient filters for waters emerging at the soil surface.

High herbaceous plant production is one of the key factors for maintaining ecosystem services, by promoting carbon sequestration and nutrient conservation from the terrestrial landscape. A factor such as grazing, which influences

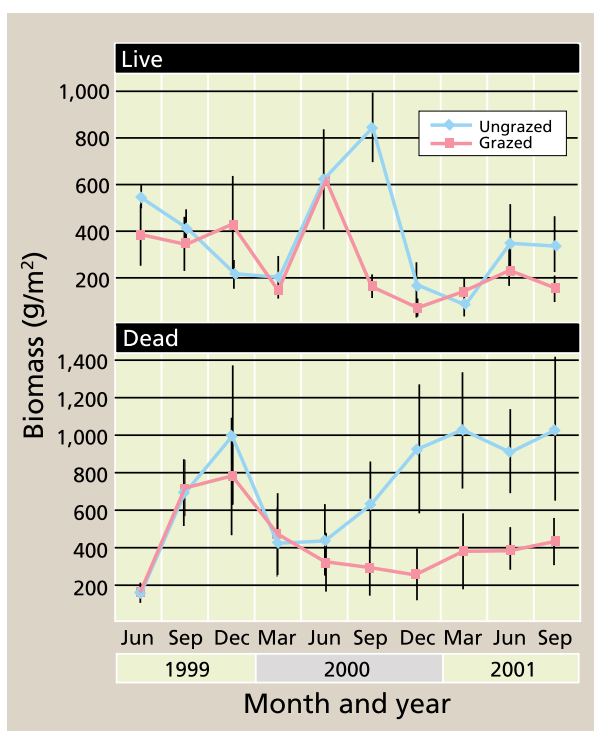

Fig. 4. Live and dead plant biomass from grazed and ungrazed plots in Experiment $B$.

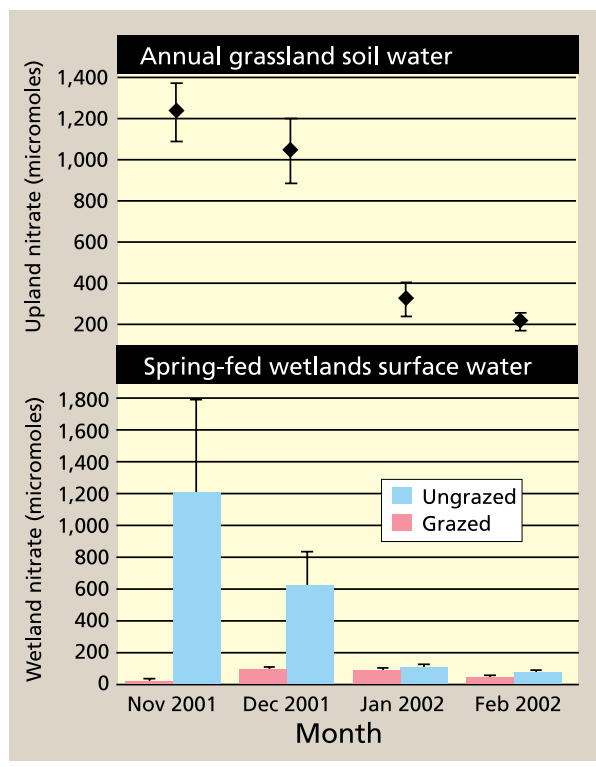

Fig. 5. Soil and surface-water nitrate concentrations from Experiment $B$ during winter 2001-2002.

ecosystem productivity, is an important control on ecosystem services.

Livestock grazing also shapes plant communities in these systems. Our studies show that nutrients (nitrogen) from the surrounding environment flow into the spring systems, supporting great productivity in concert with water and energy surpluses. Removal of livestock grazing resulted in increased levels of nitrate in wetland waters and thus higher levels of nitrate pollution compared to grazed springs. When grazing was removed, these 


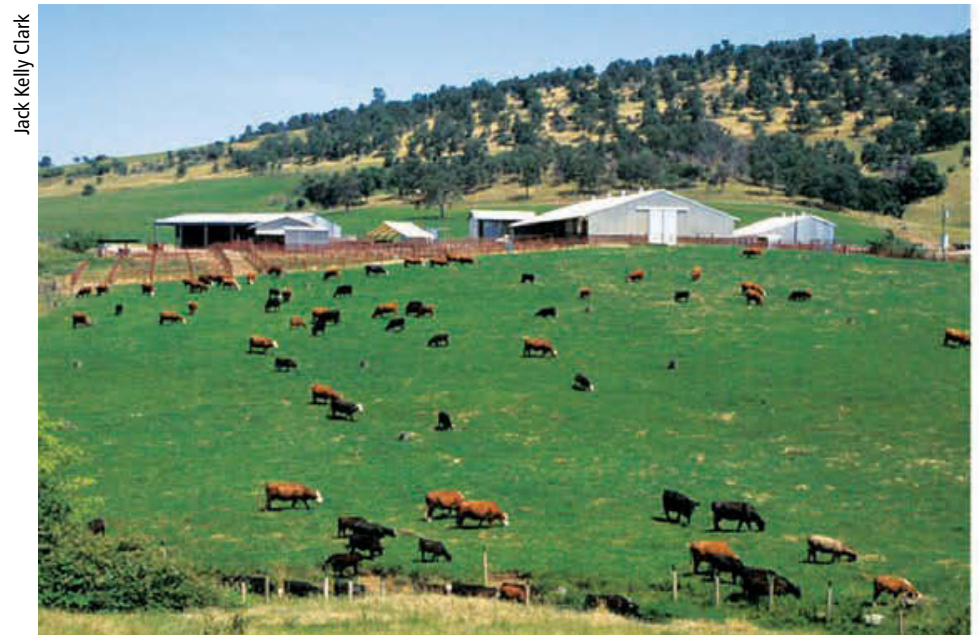

Research on the ecological impacts of cattle grazing was conducted over a 10-year period at the UC Sierra Foothill Research and Extension Center in Browns Valley (near Marysville).

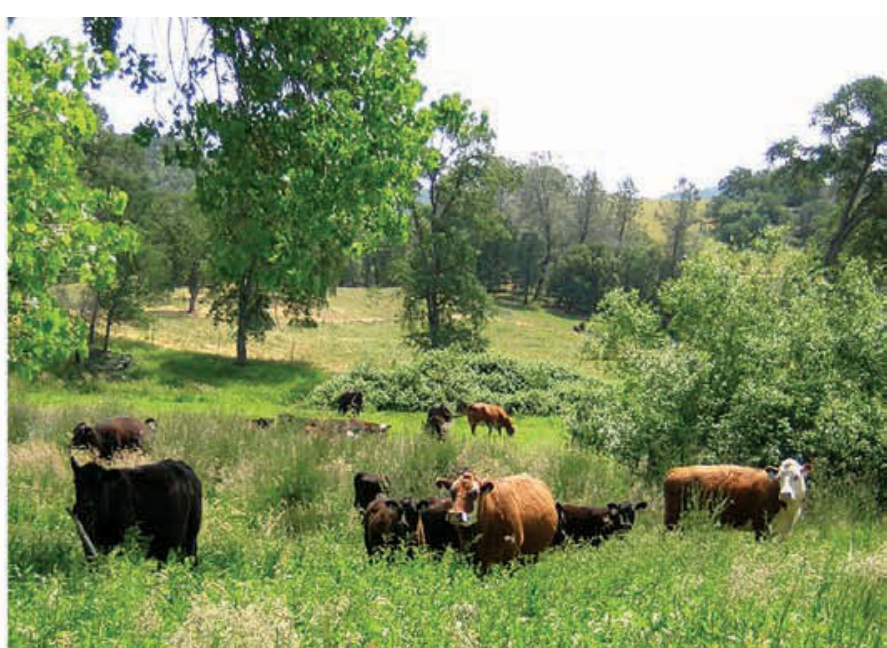

Spring-wetland ecosystems evolved with grazing wildlife, and later domestic animals. Light livestock grazing fosters plant diversity and helps to maintain nitrate levels in spring waters. systems underwent greater changes in plant composition resulting in decreased plant diversity. Some degree of herbivory appears desirable from an ecosystem function perspective, although consistently high grazing intensities will reduce herbaceous cover to undesirable levels.

Future work should examine ecosystem interactions with the atmosphere as greenhouse-gas concentrations continue to rise. The removal of livestock grazing from these systems, especially during the early summer when the combination of temperature and soil water is at an optimal level for methane production, may reduce methane emissions. However, nitrate levels in spring waters increase with grazing removal, and preliminary data shows that grazing removal also increases the production of the greenhouse gas nitrous oxide $\left(\mathrm{N}_{2} \mathrm{O}\right)$.

In addition to introduced cattle, spring-wetland systems are grazed by wildlife of all kinds. Grazing is an integral part of these systems; it evolved with them, and the plants and wildlife grazers (and later domestic grazers) are adapted and continue to adapt to each other. These studies demonstrate the importance of and need for longterm research, and show that tradeoffs exist for different management scenarios and different measured environmental factors.

\section{B. Allen-Diaz is Professor, J.W. Bartolome is} Professor, and L.G. Oates is Graduate Student, Department of Environmental Science, Policy and Management (ESPM) - Ecosystem Sciences, UC Berkeley; R.D. Jackson is Assistant Professor, University of Wisconsin, Madison (formerly ESPM Post-Doctoral Student); and K.W. Tate is UC Cooperative Extension Specialist, Department of Agronomy and Range Science, UC Davis. Thanks to students Katie Phillips, Shelly Evans, Jeff Fehmi, Chris Campbell, Mark Spencer, Aimee Betts, Eric Hammerling and Clay Taylor. Special thanks to Mike Connor, Dave Labadie and the SFREC staff for years of help and support, and to the UC Integrated Hardwood Range Management Program for funding.

\section{References}

Allen-Diaz B, Jackson RD. 2000. Grazing effects on spring ecosystem vegetation of California's hardwood rangelands. J Range Manage 53:215-20.

Allen-Diaz B, Jackson RD. 2002. Grazing California's oak woodlands: Ecological effects and the potential for conservation management. In: Planning for Biodiversity: Bringing Research and Management Together; Feb 29-March 2, 2000; Pomona, CA.

Allen-Diaz B, Jackson RD, Fehmi JS. 1998. Detecting channel morphology change in

California's hardwood rangeland spring ecosystems. J Range Manage 51:514-8.

Allen-Diaz B, Jackson RD, Phillips K. 2001. Spring-fed plant communities of California's East Bay hills oak woodland. Madroño 48: 98-111.
Bartlett KB, Harriss RC. 1993. Review and assessment of methane emissions from wetlands. Chemosphere 26:261-320.

Bouwman AF. 1990. Exchange of greenhouse gases between terrestrial ecosystems and the atmosphere. In: Bouwman (ed.). Soils and the Greenhouse Effect. New York: J Wiley. p 25-32.

Campbell CG, Allen-Diaz B. 1997. Livestock Grazing and Riparian Habitat Water Quality: An Examination of Oak Woodland Springs in the Sierra Foothills of California. USDA Forest Service PSW-GTR-160. USDA Pacific Southwest Forest and Range Research Station. p 339-46.

Cicerone RJ, Oremland RS. 1988. Biogeochemical aspects of atmospheric methane. Global Biogeochem Cycles 2:299-327.

Hickman JC. 1993. Jepson Manual. Berkeley, CA: UC Pr. 1,400 p.

Jackson RD. 2002. Structure and function of spring-fed wetlands in an oak savanna. UC Berkeley, PhD dissertation.

Jackson RD, Allen-Diaz B. 2002. Nitrogen dynamics of spring-fed wetland ecosystems of the Sierra Nevada foothills oak woodland. 5th Symposium on Oak Woodlands: Oaks in California's Changing Landscape; October 22-5, 2001; San Diego, CA. p 119-29.

McCune B, Grace JG. 2002. Analysis of Ecological Communities. Gleneden Beach, Ore.: MjM Software Design. 300 p.

Oates LG. 2002. The effect of grazing on methane emissions from spring-fed wetlands in a California oak savanna. UC Berkeley Dept of Environmental Science, Policy and Management. Senior honors thesis.

Schlesinger WH. 1997. Biogeochemistry: An Analysis of Global Change. San Diego, CA: Academic Pr.

Tyler SC. 1991. The global methane budget. In: Rogers JE, Whitman WB (eds.). Microbial Production and Consumption of Greenhouse Gases: Methane, Nitrogen Oxides and Halomethanes. Washington, DC: American Soc Microbiol. p 7-38. 